\title{
Novo milênio, novo século, novos e maiores desafios
}

As conseqüências deletérias do processo da Globalização se fazem sentir cada vez mais, em especial nos países em desenvolvimento. Grandes contingentes de nossas populações sofrem o processo de exclusão social, desemprego e a cada vez mais perversa concentração de renda. As políticas sociais implementadas por países que encontram limitações nos gastos públicos, dívida interna e externa crescentes e lacunas em termos da infra-estrutura dos serviços públicos não conseguem dar conta dos desafios do dia a dia. A política de saúde representa, sem dúvida nenhuma, a grande esperança das populações excluídas para assegurar melhores condições de saúdee, portanto, mel hor qualidade de vida.

O Brasil vem debatendo intensamente a necessidade de implementar políticas sociais, entre elas a política de saúde, que venham contribuir para a melhoria das condições de vida da população. Um exemplo foi a realização da 11ạ Conferência Nacional de Saúde em dezembro de 2000, evento que anal isou a implementação do Sistema Ú nico de Saúde no contexto do atual modelo econômico em nosso país. Busca-se na discussão cumprir e fazer cumprir a determinação constitucional de assegurar a Saúde como direito de todos e dever do Estado, com princípios como universalidade, eqüidade e integralidade.

Mais recentemente, a sistematização efetuada pelo Ministério da Saúde para as ações de saúde em andamento passíveis de medição por intermédio de indicadores, queresultaram na proposta de Agenda Nacional de Saúde para 2001 (Portaria № 393/ GM , de 29 de março de 2001), como instrumento fundamental para a orientação estratégica da política de saúde no Brasil, agrupou em seis eixos prioritários de intervenção as ações a serem implementadas no âmbito das três esferas de governo. A redução da mortalidade infantil e materna; o controle de doenças e agravos prioritários; a reorientação do modelo assistencial e descentralização; a melhoria da gestão, do acesso e da qualidade das ações e serviços de saúde; o desenvolvimento de recursos humanos do setor saúde; e a qualificação do controle social, passam a constituir referenciais prioritários no processo de planejamento em saúde.

Em nível mundial, as autoridades de saúde dos países em desenvolvimento também manifestam preocupação com a necessidade de discutir e encontrar propostas de intervenção capazes de mel horar a qualidade de vida dos habitantes destes países, al guns paupérrimos e fragi lizados pela el evada prevalência de endemias, epidemias e pandemias.

Saúde e Ambiente; Segurança Alimentar; Nutrição; Desenvolvimento Sustentável; Saúde da Mulher, da Criança e do Adolescente; Saúde Reprodutiva; Vigilância, Prevenção, Erradicação e Controle de Doenças Transmissíveis; Organização de Servi ços de Saúde; Acesso, Qualidade e Uso Racional de Medicamentos Essenciais; Desenvolvimento deVacinas e Imunização; Segurança Transfusional; Prevenção e Manejo de Doenças Não-Transmissíveis; Promoção da Saúde; Saúde Mental: Estes são alguns dos temas prioritários que vêm sendo discutidos em escala mundial nas últimas Assembléias Mundiais da Saúde e reuniões internacionais decorrentes de Resoluções aprovadas nestes foros.

A Escola Nacional de Saúde Pública inicia uma nova gestão de quatro anos, reforçando profundos compromissos com a superação desta realidade, contribuindo no âmbito de suas áreas de atuação para viabilizar ações concretas. Desta manei ra, cabe ressaltar que suas atividades oferecem suporte a todos os ei xos de intervenção da Agenda Nacional de Saúde para 2001, tanto na prestação direta de serviços à comunidade como na reflexão e produção do conhecimento ou na proposta de estratégi as de intervenção. Adicionalmente, a grande maioria dos temas prioritários que vem sendo debati dos em escala mundial fazem parte do desafio de nossas atividades no dia-a-dia.

Um novo Milênio e um novo Século, sem dúvida nos instigam a enfrentar, cada vez mais, novos e maiores desafios, que serão respondidos na medida da nossa capacidade coletiva de potencializar e otimizar o conhecimento acumulado nesta Escola ao longo de quase cinqüenta anos a serviço da construção de um Brasil mais humano e solidário.

Jorge A. Z. Bermudez

Diretor da Escola Nacional deSaúde Pública, Fundação Oswaldo Cruz 


\section{A new millennium, a new century, and new and greater challenges}

The harmful consequences of the Globalization process are being increasingly felt, especially in the developing countries. Major contingents of the population in our countries are suffering from social exclusion, unemployment, and an increasingly unequal distribution of income. Social policies implemented by countries faced with severe restrictions in public expenditures, growing internal and external indebtedness, and gaps in the public services infrastructure fail to meet routine challenges. Health policy becomes the great hope for excluded populations to ensure better health conditions and thus better quality of life.

Brazil has conducted an intense debate over the need to implement social policies, including health policies, that effectively contribute to the improvement of living conditions for the country's population. A recent example was the 11th National Health Conference in December 2000, a participatory event that analyzed the implementation of the Unified National Health System in the context of the country's prevailing economic model. The discussion focused on compliance with the Constitutional provision according to which health is the right of all and the duty of the state, based on such principles as universal, equitable, and integral coverage.

More recently, the Ministry of Health undertook a systematic analysis of current health activities that can be measured by way of indicators, resulting in the proposal of a National Health Agenda for 2001 (Ruling \#393/ GM, March 29, 2001) as a fundamental instrument for the strategic orientation of health policy in Brazil and establishing six groups of guidelines for planning and intervention at the three levels of government: reduction of infant and maternal mortality; control of priority diseases and injuries; reorientation and decentralization of the health care model; improvement of management, access, and quality of health actions and services; development of human resources for the health sector; and qualification of social control.

At the international level, health authorities in devel oping countries have al so expressed their concern over the need to discuss and implement proposals capable of improving the quality of life of their peoples, many of which have been left ravaged and destitute by the high prevalence of endemic, epidemic, and pandemic diseases.

Health and the Environment; Food Security; Nutrition; Sustainable Development; Health of Women, Children, and Adolescents; Reproductive Health; Surveillance, Prevention, Eradication, and Control of Transmissible Diseases; Organization of Health Services; Access to, Quality, and Rational Use of Essential Drugs and Medicines; Development of Vaccines and Immunization; Safety in Blood and Blood Product Transfusion; Prevention and Treatment of Non-Communicable Diseases; Health Promotion; Mental Heal th. These are some of the priority issues that have been discussed on a worldwide scale in recent World Health Assemblies and international meetings resulting from the Resolutions approved at these forums.

The National School of Public Health is beginning a new four-year administration, reinforcing a profound commitment to surmount and transform this reality, contributing within its sphere of activity to implement concrete measures. It is thus important to highlight that the administration's activities provide support for all the areas of intervention from the National Health Agenda for 2001, both in the direct provision of services to the community and in the discussion and production of knowledge and proposed strategies for intervention. In addition, the vast majority of the priority themes discussed worldwide are part of the challenge of our routine activities.

A new Millennium and a new Century will certainly encourage us to tackle new and greater challenges, which will be met through our collective capacity to empower and optimize the knowledge accumulated by this School over the course of nearly fifty years of service in building a more humane Brazil, with greater solidarity.

Jorge A. Z. Bermudez

Dean, Escola Nacional de Saúde Pública, Fundação Oswaldo Cruz 